\title{
Study of mural painting isolates, leading to the transfer of 'Bacillus maroccanus' and 'Bacillus carotarum' to Bacillus simplex, emended description of Bacillus simplex, re-examination of the strains previously attributed to 'Bacillus macroides' and description of Bacillus muralis
} sp. nov.

Correspondence
Jeroen Heyrman
Jeroen.Heyrman@UGent.be

\author{
Jeroen Heyrman, ${ }^{1}$ Niall A. Logan, ${ }^{2}$ Marina Rodríguez-Díaz, ${ }^{2}$ \\ Patsy Scheldeman, ${ }^{3}$ Liesbeth Lebbe, ${ }^{1}$ Jean Swings, ${ }^{1,4}$ \\ Marc Heyndrickx ${ }^{3}$ and Paul De Vos ${ }^{1}$
${ }^{1}$ Vakgroep BFM WE10V, Laboratorium voor Microbiologie, Universiteit Gent, K. L. Ledeganckstraat 35, B-9000 Gent, Belgium
${ }^{2}$ Department of Biological and Biomedical Sciences, Glasgow Caledonian University, Cowcaddens Road, Glasgow G4 OBA, UK
${ }^{3}$ Department of Animal Product Quality, Brusselsesteenweg 370, B-9090 Melle, Belgium
${ }^{4}$ BCCM/LMG Bacteria Collection, K. L. Ledeganckstraat 35, B-9000 Gent, Belgium

Published online ahead of print on 22 October 2004 as DOI 10.1099/ ijs.0.63221-0.

The GenBank/EMBL/DDBJ accession number for the $16 \mathrm{~S}$ rRNA gene sequence of Bacillus muralis sp. nov. LMG $20238^{\top}$ is AJ628748.

An ARDRA-based dendrogram and details of DNA-DNA hybridization results are available as supplementary material in IJSEM Online.

\section{INTRODUCTION}

Gottheil (1901) described Bacillus simplex and believed that 'Bacillus carotarum' (Koch, 1888) and 'Bacillus cohaerens' were possibly synonyms. 'Bacillus capri', 'Bacillus cobayae' and 'Bacillus musculi' were mentioned as other possible synonyms of ' $B$. carotarum' by Stapp (1920). Since the 
original 'B. carotarum' strains were lost, Gibson \& Gordon (1974) proposed 'B. capri' strain NRS 607 as the representative of the species. Hunger \& Claus (1981) showed that the DNA-DNA relatedness between ' $B$. carotarum' NRS 607 and B. simplex was around $70 \%$, the borderline for species delineation. Priest et al. (1988) studied 368 strains, including ' $B$. carotarum' and B. simplex, by 118 phenotypic tests. In the resulting clustering, B. simplex and 'B. carotarum' strains grouped together. Despite this close relatedness and regardless of the DNA-DNA hybridization data of Hunger \& Claus (1981), Priest et al. (1988) concluded from their study that ' $B$. carotarum' and B. simplex were distinct taxa and gave a species description of $B$. simplex (later validated; Priest et al., 1989).

'Bacillus maroccanus' (Delaporte \& Sasson, 1967) was included, together with B. simplex, in the phylogenetic studies of Ash et al. (1991) and Xu \& Côté (2003). In both studies, 'B. maroccanus' and B. simplex clustered closely together. However, to our knowledge no DNA-DNA hybridization studies between these two taxa have been published to date.

'B. macroides' was originally described as 'Lineola longa' (Pringsheim \& Robinow, 1947; Pringsheim, 1950), until Bennett \& Canale-Parola (1965) demonstrated endospore formation and a positive Gram-stain in this ostensibly Gram-negative, non-sporulating taxon. Two different ' $B$. macroides' strains are available: ATCC 12905 ( = DSM 54), on which the original description is based, and NCIMB 8796 ( = NCDO 1661) of which a $16 \mathrm{~S}$ rRNA gene sequence is available (GenBank/EMBL accession number X70312). The sequence of the latter shows high similarity to sequences of B. simplex and 'B. maroccanus', while Xu \& Côté (2003) recently demonstrated that strain ATCC 12905 shares highest similarity with Bacillus fusiformis and Bacillus sphaericus based on comparison of $3^{\prime}$-end 16S rRNA gene and $5^{\prime}$-end 16S-23S ITS sequences. Since the phenotypic characters of ' $B$. macroides' also conform to those of $B$. sphaericus, except for sporangial morphology (Claus \& Berkeley, 1986), it can be concluded that ATCC 12905 is the original ' $B$. macroides' strain.

The finding of isolates from deteriorated wall paintings with high 16S rRNA gene sequence similarity to ' $B$. macroides' strain NCIMB 8796 (Heyrman \& Swings, 2001) and consequently the need for their classification, led in this study to the revision of the taxonomic position of strains previously attributed to ' $B$. macroides', ' $B$. maroccanus' and ' $B$. carotarum' and to the proposal of the novel species Bacillus muralis sp. nov. to accommodate five mural painting isolates.

\section{METHODS}

Strains and media. The mural painting isolates originate from two severely damaged mural painting sites, the Servilia tomb of the Roman necropolis of Carmona (Spain) and the Lutheran church of Greene-Kreiensen (Germany). The Carmona strains were isolated from a sample of powdery growth on the painted wall at the left of the main entrance of the tomb, at a height of $1.8 \mathrm{~m}$. The Greene strains originate from sampling of ochre-coloured, round, dry spots taken at the west wall of the church (depicting the Adoration of the Magi). Further isolate designations and methods applied are shown in Table 1. Isolates were maintained in Microbank tubes at $-80^{\circ} \mathrm{C}$. For phenotypic characterization studies, including microscopy, cultures were maintained on slopes of trypticase soy agar (TSA) containing $5 \mathrm{mg} \mathrm{MnSO}_{4} \mathrm{l}^{-1}$ (to enhance sporulation).

DNA preparation. Total genomic DNA was purified for $16 \mathrm{~S}$ rRNA gene sequencing, ARDRA and rep-PCR using a slight modification of the method of Pitcher et al. (1989), as described by Heyndrickx et al. (1996). For determination of the G $+C$ content and DNADNA hybridization, approximately $1 \mathrm{~g}$ biomass was harvested from agar plates. DNA was purified by a combination of the protocols of Marmur (1961) and Pitcher et al. (1989), as described by Logan et al. (2000).

165 rRNA gene sequencing and phylogenetic analysis. Sequence analysis was performed as previously described by Heyrman \& Swings (2001). For partial sequencing, two primers were used (reverse 358-339 and reverse 536-519; Heyrman \& Swings, 2001) to obtain the first 400-500 base pairs of the 16S rRNA gene, which according to Goto et al. (2000) includes the hypervariant region for the genus Bacillus. A phylogenetic tree was constructed using the BioNumerics 3.0 software (Applied Maths) by applying the neighbour-joining method of Saitou \& Nei (1987) on a multiple alignment similarity matrix. The stability of relationships was assessed by a bootstrap analysis of 1000 datasets.

ARDRA. Amplified 16S rRNA genes were obtained by PCR and analysed by restriction digestion with five restriction enzymes (HaeIII, $D p n I I, R s a I, B f a$ I and Tru9I) as described previously by Heyndrickx et al. (1996). The restriction patterns were analysed as described by Heyndrickx et al. (1998).

rep-PCR genomic fingerprinting. PCR was performed with the $(\mathrm{GTG})_{5}$ primer (Versalovic et al., 1994) using the PCR conditions described previously by Rademaker \& de Bruijn (1997). Electrophoretic conditions for the (GTG) $)_{5}$ PCR of the mural painting isolates (see Fig. 1a) were those described by Heyrman et al. (2003); those for the additional (GTG) $)_{5}$-PCR (see Fig. 1b) were described by Scheldeman et al. (2004). The resulting patterns were digitized and a Pearson correlation of the resulting band patterns was performed using the BioNumerics and the GelCompar software, respectively.

G $+\mathbf{C}$ content and percentage DNA-DNA binding. The $\mathrm{G}+\mathrm{C}$ content of DNA was determined by HPLC (Mesbah et al., 1989) using the further specifications given by Logan et al. (2000). DNADNA hybridization was performed using a modification of the microplate method of Ezaki et al. (1989), as described by Willems et al. (2001). A hybridization temperature of $37^{\circ} \mathrm{C}$ (calculated with correction for the presence of $50 \%$ formamide) was used.

Chemotaxonomic characterization. Gas chromatographic analysis of fatty acid methyl esters was performed starting from strains grown on TSA for $24 \mathrm{~h}$ at $28^{\circ} \mathrm{C}$. A quantitative analysis of cellular fatty acid compositions was further performed by the gas-liquid chromatographic procedure as previously described (Mergaert et al., 1993). Computer analysis of the resulting profiles was performed as described by Heyrman et al. (1999). For SDS-PAGE of whole-cell proteins, cells were obtained as described by Heyndrickx et al. (1998). SDS protein extracts were prepared and electrophoresed according to Pot et al. (1994), and the data were collected and interpreted as described by Vauterin \& Vauterin (1992).

Phenotypic characterization. The strains were phenotypically characterized by the methods of Logan \& Berkeley (1984); other 
Table 1. Strains studied and the methods used for characterization

\begin{tabular}{|c|c|c|c|c|c|c|c|c|c|}
\hline \multirow[t]{2}{*}{ Strain } & \multirow[t]{2}{*}{ Source/comments } & \multicolumn{8}{|c|}{ Methods used for characterization } \\
\hline & & FAME & PAGE & $\begin{array}{c}\text { API } \\
\text { biovar }\end{array}$ & $(\mathrm{GTG})_{5}-1$ & $(\mathrm{GTG})_{5}-2$ & $\begin{array}{c}16 \mathrm{~S} \\
\text { rRNA }^{\star}\end{array}$ & ARDRA & $\begin{array}{l}\text { DNA- } \\
\text { DNA }\end{array}$ \\
\hline \multicolumn{10}{|l|}{ Novel isolates } \\
\hline LMG 19489 (=R-5266) & Mural painting, Carmona & + & + & 1 & $\mathrm{C}$ & + & $\mathrm{F}$ & & + \\
\hline LMG 22046 (=R-5269) & Mural painting, Carmona & + & + & 2 & $\mathrm{C}$ & + & $\mathrm{P}$ & & \\
\hline R-5307 & Mural painting, Carmona & + & + & 1 & $\mathrm{~B}$ & + & & & \\
\hline $\mathrm{R}-8191$ & Mural painting, Greene & + & & 1 & A & & & & \\
\hline LMG $20238^{\mathrm{T}}\left(=\mathrm{R}-8192^{\mathrm{T}}\right)$ & Mural painting, Greene & + & + & 3 & $\mathrm{D}$ & + & $\mathrm{F}$ & & + \\
\hline $\mathrm{R}-8193$ & Mural painting, Greene & + & & 2 & A & & & & \\
\hline $\mathrm{R}-8202$ & Mural painting, Greene & + & & 2 & A & & & & \\
\hline $\mathrm{R}-8210$ & Mural painting, Greene & + & + & 3 & $\mathrm{D}$ & + & & & \\
\hline $\mathrm{R}-8214$ & Mural painting, Greene & + & & 2 & A & & & & \\
\hline LMG $21002(=\mathrm{R}-8216)$ & Mural painting, Greene & + & + & 2 & A & + & $\mathrm{F}$ & & + \\
\hline $\mathrm{R}-8218$ & Mural painting, Greene & + & & 2 & A & & & & \\
\hline $\mathrm{R}-8220$ & Mural painting, Greene & + & + & 2 & A & + & & & \\
\hline $\mathrm{R}-8225$ & Mural painting, Greene & + & & - & A & & & & \\
\hline $\mathrm{R}-8231$ & Mural painting, Greene & + & & 2 & A & & & & \\
\hline $\mathrm{R}-8234$ & Mural painting, Greene & + & + & 2 & A & + & & & \\
\hline LMG $21004(=\mathrm{R}-8249)$ & Mural painting, Greene & + & + & 3 & $\mathrm{D}$ & + & $\mathrm{P}$ & & \\
\hline $\mathrm{R}-8251$ & Mural painting, Greene & + & + & 3 & $\mathrm{D}$ & + & & & \\
\hline $\mathrm{R}-8253$ & Mural painting, Greene & + & & 2 & A & & & & \\
\hline $\begin{array}{l}\text { LMG } 18508(=\text { NCIMB } 8796 \\
=1745-1 \mathrm{~b})\end{array}$ & & + & & 1 & & & EMBL & + & + \\
\hline \multicolumn{10}{|l|}{ 'B. carotarum' } \\
\hline LMG $17633(=$ B0079) & Dust, Gibson & & + & 2 atypical & & + & $\mathrm{F}$ & + & \\
\hline LMG $17634(=\mathrm{B} 0272)$ & Gibson & + & + & 1 & & + & & + & \\
\hline LMG $17636(=$ B0976) & Unpasteurized milk, Gibson & & + & 1 & & + & $\mathrm{F}$ & + & + \\
\hline LMG $17637(=$ B0993) & $=$ NRS 607, Gibson & & + & 2 & & + & & & \\
\hline LMG $17638(=\mathrm{B} 1044)$ & Gibson & & + & 1 & & + & & + & \\
\hline LMG $17639(=\mathrm{B} 1050)$ & Gibson & & + & 2 & & + & & + & \\
\hline LMG $17640(=$ B0081) & Soil, Gibson & & + & 1 & & + & & + & \\
\hline LMG $17642(=$ B0788) & Mucoid, Keates & & + & 2 & & + & & & \\
\hline LMG $17643(=$ B0984) & Gibson & & + & 1 & & + & & + & \\
\hline LMG 17644 (= B0997) & Gibson & & & 1 & & + & & + & \\
\hline LMG $17646(=\mathrm{B} 1373)$ & Flour, FMBRA & & + & 2 & & + & & + & \\
\hline \multicolumn{10}{|l|}{ Unidentified strains } \\
\hline Bacillus sp. R-15936 (=B2456) & Clinical isolate & + & + & 1 & & + & & + & \\
\hline Bacillus sp. R-15943 (=B2543) & Antarctic soil, Russel & + & & 1 & & + & & + & \\
\hline
\end{tabular}

${ }^{\star}$ EMBL, Sequence obtained from EMBL database; F, sequenced fully; P, partial sequence. 
(a) Pearson's correlation

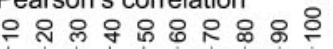
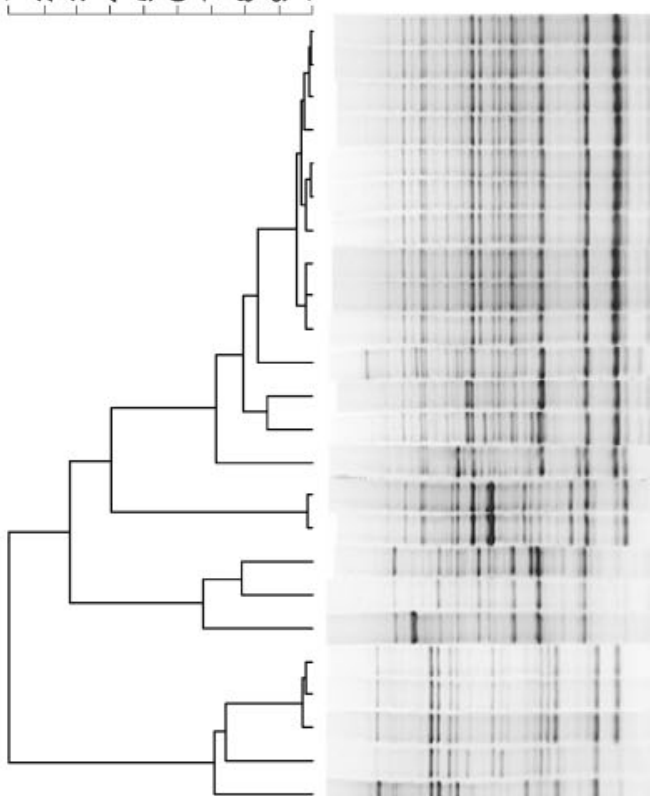

R-8231

R-8234

R-8225

$\mathrm{R}-8218$

R-8207

R-8193

LMG 21002

R-8253

R-8254

R-8214

R-8191

R-8220

$\mathrm{R}-8208$

R-8202

LMG 22045

R-5307

LMG 22046

R-5275

LMG 19489

LMG 21004

R-8251

$\mathrm{R}-8210$

R-8204

LMG 20238'
Group A

Group B

Group C

Group D

(b) Pearson's correlation

\section{으워잉ㅇㅁㅇㅇㅇㅇㅇㅇㅇㅇ응}

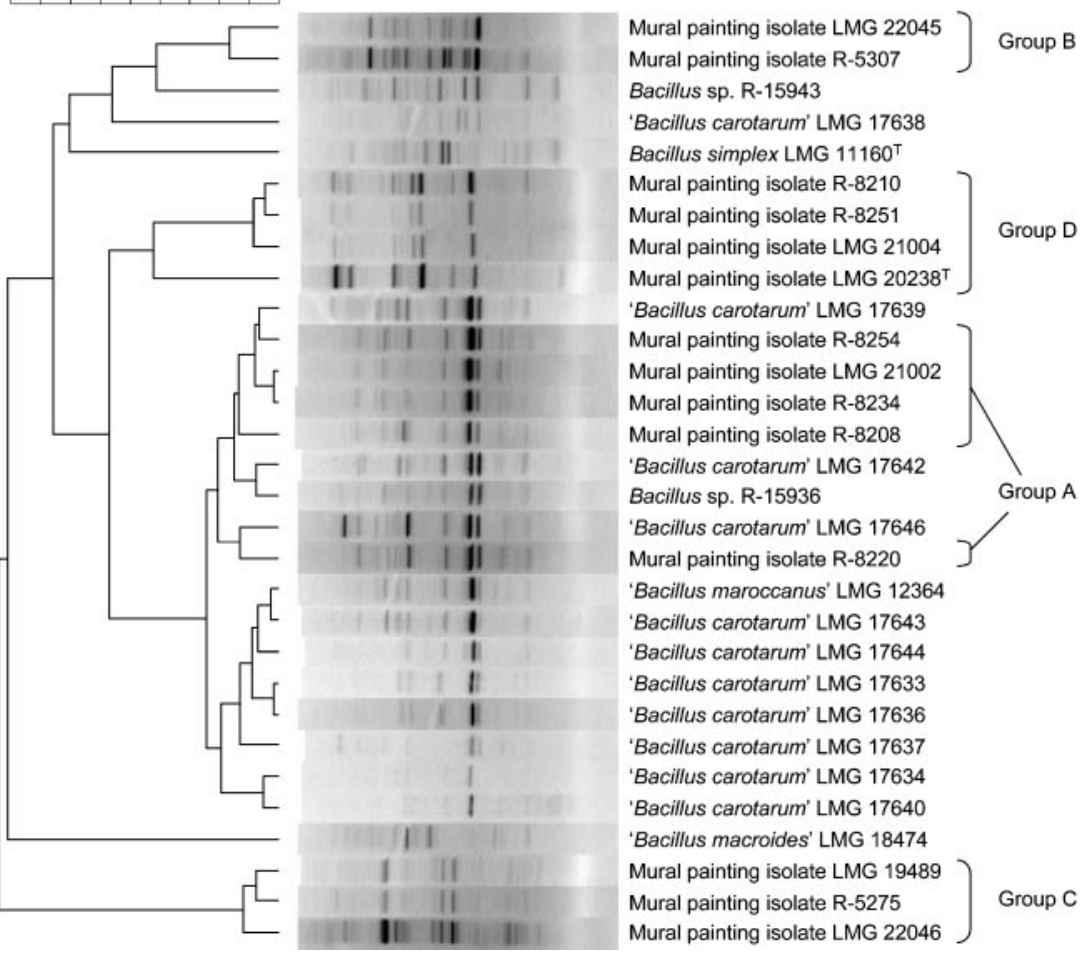

Fig. 1. (a) Grouping of normalized (GTG) 5 patterns (using the electrophoretic conditions described by Heyrman et al., 2003 ) of 24 mural painting isolates. (b) Grouping of normalized (GTG) 5 patterns (using the electrophoretic conditions described by Scheldeman et al., 2004) of representative mural painting isolates together with the $B$. simplex type strain, ' $B$. macroides' LMG 18474 (=DSM 54=ATCC 12905), ' $B$. maroccanus', strains belonging to ' $B$. carotarum' and additional isolates R-15936 and R-15943. Both dendrograms are based on a UPGMA clustering of Pearson's correlation similarity coefficients. 
characters were determined, and the data numerically analysed, as described by Logan et al. (2000). For strains that give very few positive reactions in these phenotypic tests, the inclusion of negative results in similarity calculations tends to overemphasize the similarities of these organisms; data for unreactive strains in this study were therefore analysed by omitting negative matching characters from the calculations. Vegetative cells and sporangia were observed by phase-contrast microscopy. Strains were also examined for catalase and oxidase production and casein and starch hydrolysis using the methods of Gordon et al. (1973). Maximum and minimum growth temperatures were determined by incubating $10 \mathrm{ml}$ TSA cultures in a water bath; $\mathrm{pH}$ ranges for growth were determined using $10 \mathrm{ml}$ TSA cultures adjusted to $\mathrm{pH} 5 \cdot 0,7 \cdot 0$ and $9 \cdot 0$; both series were examined for turbidity at $24 \mathrm{~h}$ intervals. Anaerobic growth was tested for by incubating cultures on TSA plates in a GasPak jar, with aerobically incubated plates as controls. A small number of strains were also tested for assimilation of substrates as sole carbon sources, using the API Biotype 100 kit as described by Heyndrickx et al. (1997).

\section{RESULTS AND DISCUSSION}

\section{Genomic profiling and 16S rRNA gene sequencing}

Firstly, (GTG) $)_{5}$-PCR fingerprinting was performed on the mural painting isolates to determine their genotypic diversity and to select representative strains for further analyses. The resulting electrophoretic patterns were used to construct a dendrogram based on a Pearson correlation (Fig. 1a). In this dendrogram, four clusters can be distinguished with an internal correlation above $65 \%$. These clusters of strains are called (GTG) $)_{5}$-groups A to D. The mural painting strains had clustered according to geographical origin, with the Carmona (Spain) strains divided between (GTG) ${ }_{5}{ }^{-}$ groups B and C, and the Greene (Germany) strains between groups $\mathrm{A}$ and $\mathrm{D}$.

Six representative strains were chosen for partial sequencing (463 bases) of the hypervariable region for Bacillus of the
16S rRNA gene (Goto et al., 2000): one of (GTG) 5 -groups A and B (LMG 21002 and LMG 22045, respectively) and two of groups C and D (LMG 19489 and LMG 22046; LMG 21004 and LMG $20238^{\mathrm{T}}$, respectively). The strains of groups A, B and C, had identical partial sequences, while the two strains of group D were almost identical to each other (one extra base in the sequence of LMG $20238^{\mathrm{T}}$ ). Comparison of LMG 21002 (group A) and LMG $20238^{\mathrm{T}}$ (group D) revealed four base mismatches; these two strains and LMG 19489 (group C) were chosen for determination of the nearly complete 16S rRNA gene sequence. LMG 21002 showed respective sequence similarities of $99 \cdot 7$ and $99 \cdot 9 \%$ to LMG 19489 and LMG $20238^{\mathrm{T}}$, while the latter two strains had a sequence similarity of $99.5 \%$. A FASTA search (Pearson \& Lipman, 1988) of the analysed sequences showed $99 \%$ sequence similarity or higher for all three to sequences of B. simplex DSM $1321^{\mathrm{T}}$ (AJ439078), 'B. macroides' NCIMB 8796 (X70312), two sequences (AY030319 and AF157696) attributed to ' $B$. macroides' on the basis of comparative analysis with X70312, and some additional unnamed strains (Fig. 2). The $16 \mathrm{~S}$ rRNA gene sequences of $B$. simplex DSM $1321^{\mathrm{T}}$ (X60638) and 'B. maroccanus' NCIMB 10500 (X60626) analysed by Ash et al. (1991) could not be retrieved from the FASTA results, because these sequences contain large numbers of unknown bases (61 and 25, respectively). When their unknown bases were discarded, high sequence similarities $(>99.5 \%)$ to the sequences deposited as AJ439078 (B. simplex) and X70312 (' $B$. macroides') were also demonstrated. Since the sequence AJ439078 for B. simplex was only recently deposited in the international sequence databases, several strains were attributed previously to ' $B$. macroides' because of their high sequence similarity to strain NCIMB 8796 (X70312). However, 'B. macroides' NCIMB 8796 differs importantly from ATCC 12905, the strain on which the original description of 'B. macroides' was based. Xu \& Côté (2003) compared the $3^{\prime}$-end $16 \mathrm{~S}$ rRNA gene and $5^{\prime}$-end 16S-23S

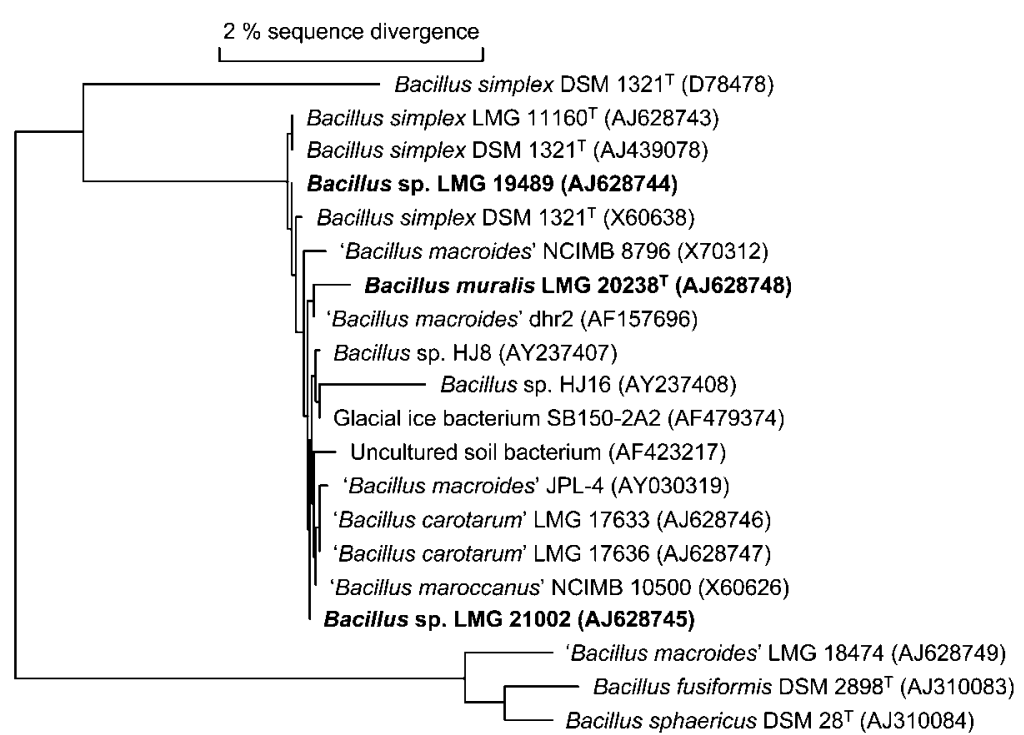

Fig. 2. Unrooted phylogenetic tree derived from the analysis of $16 \mathrm{~S}$ rRNA gene sequences of mural painting isolates (in bold) together with strains that were attributed to $B$. simplex and the species ' $B$. macroides', 'B. maroccanus' and ' $B$. carotarum'. 
ITS nucleotide sequences of 40 species of the Bacillaceae and showed that 'B. macroides' ATCC 12905 showed highest similarity to B. sphaericus and B. fusiformis. In the present study, the nearly complete $16 \mathrm{~S}$ rRNA gene sequence of strain LMG 18474 (=DSM $54=$ ATCC 12905) was determined and B. sphaericus and B. fusiformis were indeed retrieved as the closest related species on the basis of the respective sequence similarities of 98.4 and $98.7 \%$. In the original description, the phenotypic characters of ' $B$. macroides' were similar to those of $B$. sphaericus, except for sporangial morphology (Claus \& Berkeley, 1986). This led to the conclusion that strain NCIMB 8796 is taxonomically different from ' $B$. macroides' as represented by LMG 18474 (=DSM 54=ATCC 12905). In a phylogenetic tree, strain NCIMB 8796 clustered closely with strains belonging to $B$. simplex and strains that were named ' $B$. maroccanus'. In this tree, three sequences are present that are all presumed to belong to the B. simplex DSM $1321^{\mathrm{T}}$, although one of them (D78478) is clearly distinct from the other two. To assess which sequence was erroneously linked with the type strain of this species, we also determined the $16 \mathrm{~S}$ rRNA gene sequence of $B$. simplex LMG $11160^{\mathrm{T}}$ (AJ628743). The sequence with accession number D78478 remained separate and was therefore regarded as aberrant; the presence of such sequences in the databases that are erroneously attributed to type strains results in faulty interpretations. No 16S rRNA gene sequences of named 'B. carotarum' strains were available in the international databases. Since a close relatedness could be expected from the literature between named ' $B$. carotarum' strains and B. simplex (see Introduction), 16S rRNA gene sequences of LMG 17633 and LMG 17636 were determined. They were identical and showed $99 \cdot 7 \%$ sequence similarity to B. simplex (AJ439078 and AJ628743), corresponding to 4 base mismatches, confirming the close relatedness between 'B. carotarum' and B. simplex.

As a result of this sequence analysis that was supported by other data (see Introduction), a separate (GTG) $)_{5}$ PCR fingerprinting experiment (using different electrophoretic conditions, see Methods) was performed on 14 representative mural painting isolates, the B. simplex type strain, strains previously attributed to ' $B$. macroides' (strain DSM 54), 'B. maroccanus' (LMG 12364) and 'B. carotarum' and two additional isolates, R-15936 and R-15943 (Fig. 1b). Numerical analysis of this second set of $(\mathrm{GTG})_{5}$ data revealed that most strains named ' $B$. carotarum', the ' $B$. maroccanus' strain and the mural painting isolates attributed to (GTG) ${ }_{5}$-group A formed a tight cluster with a Pearson correlation above $70 \%$. Strains of (GTG) $5_{5^{-}}$ group B clustered at more than $80 \%$ correlation and were joined by clinical isolate R-15943 at $60 \%$. B. simplex LMG $11160^{\mathrm{T}}$, 'B. carotarum' LMG 17638 , 'B. macroides' LMG 18474 ( = DSM 54) and (GTG) ${ }_{5}$-groups C and D clustered separately ( $<50 \%$ relatedness to other profiles).

In addition, the named 'B. carotarum' strains, 'B. macroides' strains LMG 18474 and LMG 18508 and 'B. maroccanus' were analysed together with B. simplex by ARDRA (see Supplementary Fig. A available in IJSEM Online). A cluster at $90 \%$ or more pattern similarity was obtained for all 'B. carotarum' strains, 'B. maroccanus' LMG 12364 and 'B. macroides' LMG 18508 ( = NCIMB 8796) that was joined by the B. simplex type at $88 \%$ similarity. The pattern of the named ' $B$. macroides' strain LMG 18474 (=DSM 54) was only $70 \%$ similar to that of the other strains.

The results above showed that the mural painting strains belonging to (GTG) $)_{5}$-group A grouped together with ' $B$. carotarum' and ' $B$. maroccanus'. Furthermore, these strains were also similar to the type strain of $B$. simplex, ' $B$. macroides' NCIMB 8796 and the other mural painting strains. However, 'B. macroides' strains LMG 18474 ( = DSM $54=$ ATCC 12905) and LMG 18508 (=NCIMB 8796) clearly belong to separate taxa. DNA-DNA hybridization experiments were performed to determine the exact taxonomic position of the investigated strains.

\section{DNA-DNA hybridization and DNA base composition}

On the basis of rep-PCR fingerprinting, 16S rRNA gene sequencing and ARDRA, strains were selected for DNADNA relatedness studies. The results (Supplementary Table A) show that the mural painting strains belonging to (GTG) $)_{5}$-groups $A, B$ and $C$, ' $B$. maroccanus' and ' $B$. carotarum' belong to $B$. simplex (relatedness values $>70 \%$ ), according to the current species definition (Stackebrandt et al., 2002). For 'B. carotarum', these data are in accordance with those of Hunger \& Claus (1981), who performed a DNA-DNA hybridization experiment between NRS 607, proposed as a representative strain of ' $B$. carotarum' by Gibson \& Gordon (1974), and B. simplex NRS $960^{\mathrm{T}}$ and found a DNA-DNA relatedness value of $71 \%$.

Strain LMG $20238^{\mathrm{T}}$, representative of $(\mathrm{GTG})_{5}$-group D, showed less than $50 \%$ DNA-DNA relatedness to B. simplex, ' $B$. maroccanus' and the other mural painting representatives, and thus represents a novel genospecies. In the text, these strains, i.e. the $(G T G)_{5}$-group D strains, will be referred to as Bacillus muralis. As predicted from the previous analyses, ' $B$. macroides' strains LMG 18474 and LMG 18508 do not belong to the same species (DNA-DNA relatedness below $10 \%)$. Strain LMG 18508 (= NCIMB 8796 ), of which a nearly complete $16 \mathrm{~S}$ rRNA gene sequence is available (accession no. X70312), can be attributed to B. simplex (mean DNA-DNA relatedness value of $73 \cdot 4 \%$ ).

In this study, the $\mathrm{G}+\mathrm{C}$ content of the $B$. simplex type strain (LMG $11160^{\mathrm{T}}$ ) was in the range of $39 \cdot 5-41 \cdot 6 \mathrm{~mol} \%$. All tested strains that were attributed to B. simplex by DNA-DNA hybridization study have a $\mathrm{G}+\mathrm{C}$ content that falls within this range (Supplementary Table A). The $\mathrm{G}+\mathrm{C}$ content of LMG $20238^{\mathrm{T}}$ (B. muralis) is similar to that of $B$. simplex $(40 \cdot 5-41 \cdot 8 \mathrm{~mol} \%)$, while the $G+C$ content of ' $B$. macroides' LMG 18474 is slightly lower $(37 \cdot 6-38 \cdot 9 \mathrm{~mol} \%)$. 


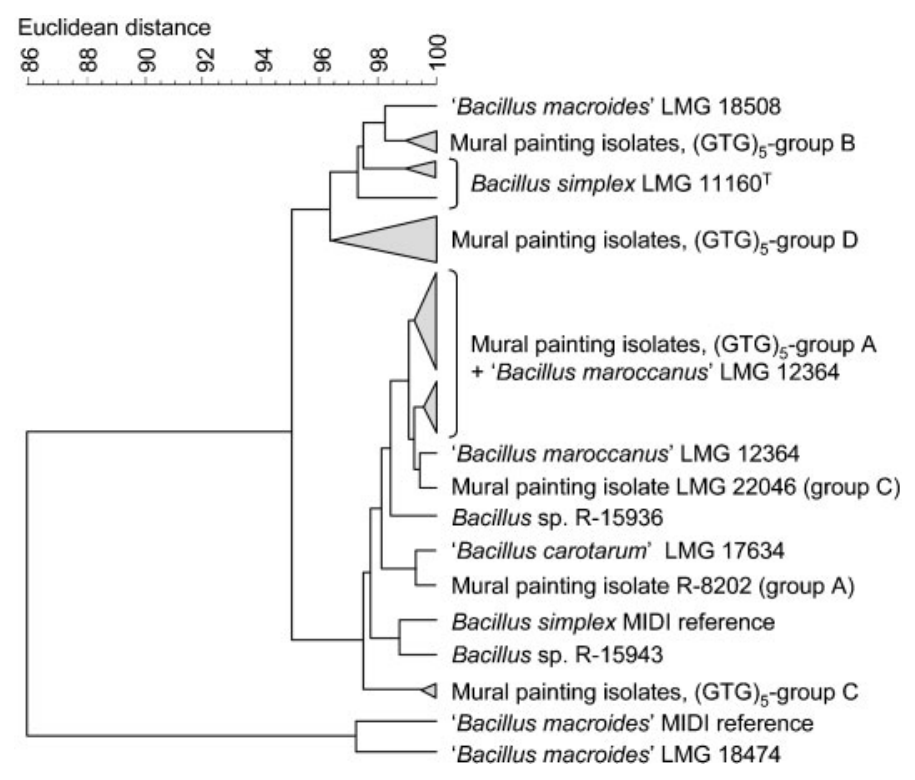

Fig. 3. Simplified dendrogram obtained by UPGMA clustering of Euclidean distances calculated between fatty acid profiles of mural painting isolates, additional isolates $\mathrm{R}-15936$ and $\mathrm{R}-15943$, B. simplex and named ' $B$. macroides', ' $B$. maroccanus' and ' $B$. carotarum' strains. For $B$. simplex and ' $B$. macroides', the MIDI reference profiles were also included.

\section{Chemotaxonomic characteristics}

Fatty acid analysis was performed on the mural painting isolates, B. simplex LMG $11160^{\mathrm{T}}$, 'B. macroides' strains LMG 18508 (=NCIMB 8796) and LMG 18474 (=DSM $54=$ ATCC 12905), 'B. maroccanus' LMG 12364, 'B. carotarum' LMG 17634 and strains R-15936 (clinical isolate) and R-15943 (Antarctic soil isolate). In Fig. 3 the resulting profiles are grouped together with the MIDI database reference profiles of $B$. simplex and ' $B$. macroides'. The outgroup (at a Euclidean distance of about $86 \%$ ) is formed by ' $B$. macroides' LMG 18474 and the database reference profile of ' $B$. macroides', which is in accordance with the earlier statement that strain LMG 18474 (=DSM $54=$ ATCC 12905) is the original ' $B$. macroides' strain, while strain LMG 18508 (=NCIMB 8796) must be allocated to B. simplex. The remaining strains form a group that is divided into two subgroups at a Euclidean distance of $95 \%$. The first subgroup contains the mural painting isolates of $(\mathrm{GTG})_{5}$-groups B and D (B. muralis) together with profiles of the B. simplex type strain and of the atypical 'B. macroides' strain, LMG 18508 (= NCIMB 8796). The second contains the mural painting isolates of $(\mathrm{GTG})_{5^{-}}$ groups $A$ and $C$, two profiles of ' $B$. maroccanus', ' $B$. carotarum' LMG 17634, R-15936, R-15943 and the MIDI reference profile of B. simplex. Except for R-15943, which showed the highest similarity to the database profile of B. simplex, the strains of the second subgroup were identified by the TSBA 4.0 MIDI database as Bacillus megaterium with similarities ranging from $0 \cdot 48$ to $0 \cdot 89$. Kämpfer (1994) already noted the close similarity of the fatty acid profiles of B. simplex and B. megaterium. The mural painting isolates that belong to the novel species $B$. muralis form a tight distinct FAME cluster. However, this cluster is embedded in a heterogeneous larger FAME group composed of strains that may all be attributed to B. simplex on the basis of genotypic analyses. It is thus not straightforward to distinguish $B$. muralis from $B$. simplex on the basis of fatty acid analysis, although small differences are clear: in comparison, $B$. muralis strains contain smaller amounts of the fatty acid anteiso- $\mathrm{C}_{15: 0}$ and higher amounts of iso- $\mathrm{C}_{15: 0}$ and $\mathrm{C}_{16: 1} \omega 11 c$ (Table 2).

Numerical analysis of SDS-PAGE patterns of whole-cell proteins (Fig. 4) revealed that, as expected from previous results, the B. simplex type strain, 'B. maroccanus', 'B. carotarum' and representative mural painting isolates showed very similar patterns (similarity $>90 \%$ ). 'B. macroides' LMG 18474 (=DSM 54=ATCC 12905) showed a distinct pattern, which confirms our earlier findings. Again, the strains of the novel species $B$. muralis group together within the larger cluster of strains that must be attributed to $B$. simplex according to our polyphasic approach.

\section{Phenotypic characterization}

The strains listed in Table 1 were investigated by the API $20 \mathrm{E}$ and API 50CHB system (bioMérieux). The phenotypic patterns obtained were compared along with the profiles of other Bacillus species, using Gower's coefficient $\left(S_{\mathrm{G}}\right)$ and omitting negative matches. In this grouping (not shown), the strains were divided between three clusters, which will be called biovars 1 to 3 (biovar 1 comprised 14 strains, biovar 2 comprised 21 strains and biovar 3 comprised 5 strains; biovars 2 and 3 each possessed a single atypical strain; Table 1). Biovar 1 strains included the type strain of B. simplex (LMG $11160^{\mathrm{T}}$ ) and 'B. macroides' LMG 18508 (=NCIMB 8796) and they differed from biovar 2 strains by generally weaker acid production from a slightly narrower range of carbohydrates (as listed in the emended description given below). Biovar 1 strains merged at only $70 \% S_{\mathrm{G}}$ and this rather heterogeneous cluster encompassed a strain of Bacillus firmus (B0823=NRS $854=\mathrm{R}-15586$ ). Strains attributed to biovar 2 formed a very loose cluster 
Table 2. Comparison of the mean fatty acid profiles of the mural painting isolates and $B$. simplex

B. simplex profiles obtained in this study and the MIDI reference are shown. The data given are mean percentages of total fatty acids $( \pm \mathrm{SD}$ if applicable). Only fatty acids accounting for at least $1.0 \%$ of the total fatty acid content are listed. Strains belonging to (GTG) ${ }_{5}$-groups A and $\mathrm{C}$ are listed together since they have similar profiles (see Fig. 3).

\begin{tabular}{|c|c|c|c|c|c|}
\hline Fatty acid & \multicolumn{4}{|c|}{ B. simplex } & $\begin{array}{c}\text { B. muralis sp. nov. } \\
\text { Group D } \\
\text { (5 strains) }\end{array}$ \\
\hline iso- $\mathrm{C}_{14: 0}$ & $4 \cdot 99 \pm 0 \cdot 65$ & $8 \cdot 93 \pm 1 \cdot 23$ & $10 \cdot 78 \pm 4 \cdot 34$ & $3 \cdot 92$ & $8 \cdot 67 \pm 4 \cdot 06$ \\
\hline $\mathrm{C}_{14: 0}$ & $1 \cdot 34 \pm 0 \cdot 12$ & $1 \cdot 36 \pm 0 \cdot 08$ & $2 \cdot 78 \pm 0 \cdot 24$ & $2 \cdot 95$ & $4 \cdot 35 \pm 1 \cdot 18$ \\
\hline iso- $\mathrm{C}_{15: 0}$ & $15 \cdot 02 \pm 2 \cdot 37$ & $21 \cdot 64 \pm 1 \cdot 22$ & $13 \cdot 53 \pm 1 \cdot 18$ & $9 \cdot 65$ & $22 \cdot 51 \pm 4 \cdot 47$ \\
\hline $\mathrm{C}_{16: 1} \omega 7 c$ alcohol & $2 \cdot 89 \pm 0 \cdot 36$ & $2 \cdot 87 \pm 0 \cdot 17$ & $3 \cdot 33 \pm 0 \cdot 60$ & $1 \cdot 84$ & $4 \cdot 11 \pm 1 \cdot 67$ \\
\hline iso- $\mathrm{C}_{16: 0}$ & $1 \cdot 75 \pm 0 \cdot 87$ & $4 \cdot 16 \pm 0 \cdot 35$ & $4 \cdot 86 \pm 1 \cdot 40$ & $2 \cdot 81$ & $1 \cdot 61 \pm 1 \cdot 00$ \\
\hline $\mathrm{C}_{16: 1} \omega 11 c$ & $4 \cdot 55 \pm 1 \cdot 34$ & $3 \cdot 08 \pm 0 \cdot 32$ & $6 \cdot 57 \pm 0 \cdot 74$ & $6 \cdot 22$ & $10 \cdot 33 \pm 2 \cdot 73$ \\
\hline $\mathrm{C}_{16: 0}$ & $1 \cdot 67 \pm 0 \cdot 49$ & $2 \cdot 32 \pm 0 \cdot 21$ & $5 \cdot 41 \pm 0 \cdot 62$ & $6 \cdot 49$ & $2 \cdot 27 \pm 0 \cdot 72$ \\
\hline Summed feature & $1 \cdot 61 \pm 0 \cdot 42$ & $<1 \cdot 0$ & $<1 \cdot 0$ & $<1 \cdot 0$ & $<1 \cdot 0$ \\
\hline anteiso- $\mathrm{C}_{17: 0}$ & $1 \cdot 88 \pm 0 \cdot 50$ & $2 \cdot 14 \pm 0 \cdot 04$ & $1 \cdot 94 \pm 0 \cdot 48$ & $2 \cdot 70$ & $<1 \cdot 0$ \\
\hline
\end{tabular}

that merged at only $65 \% S_{\mathrm{G}}$, with one atypical strain (LMG 17633) outlying at $60 \% \mathrm{~S}_{\mathrm{G}}$. This cluster contained 'B. maroccanus' LMG 12364. The mural painting strains belonging to (GTG) ${ }_{5}$-groups $\mathrm{A}, \mathrm{B}$ and $\mathrm{C}$ and the ' $\mathrm{B}$. carotarum' strains were distributed between both biovars 1 and 2. 'B. macroides' strain LMG 18474 (=DSM 54=ATCC 12905), which is believed to represent the authentic ' $B$. macroides', was unreactive in the API $50 \mathrm{CHB}$ and $20 \mathrm{E}$ tests. These results again confirm that the two strains received as ' $B$. macroides' (the unreactive LMG 18474, and
LMG 18508, which was reactive in the phenotypic tests) do not belong to the same species. When the groupings based on API 50CHB and 20E test patterns were compared with those obtained by other analyses $\left[(\mathrm{GTG})_{5}\right.$, ARDRA, SDSPAGE, FAME], biovars 1 and 2 were not distinguishable, but appeared scattered among the groups that had been recognized by those other methods.

Strains belonging to biovar 3 showed generally stronger acid production reactions over a wider range of substrates in

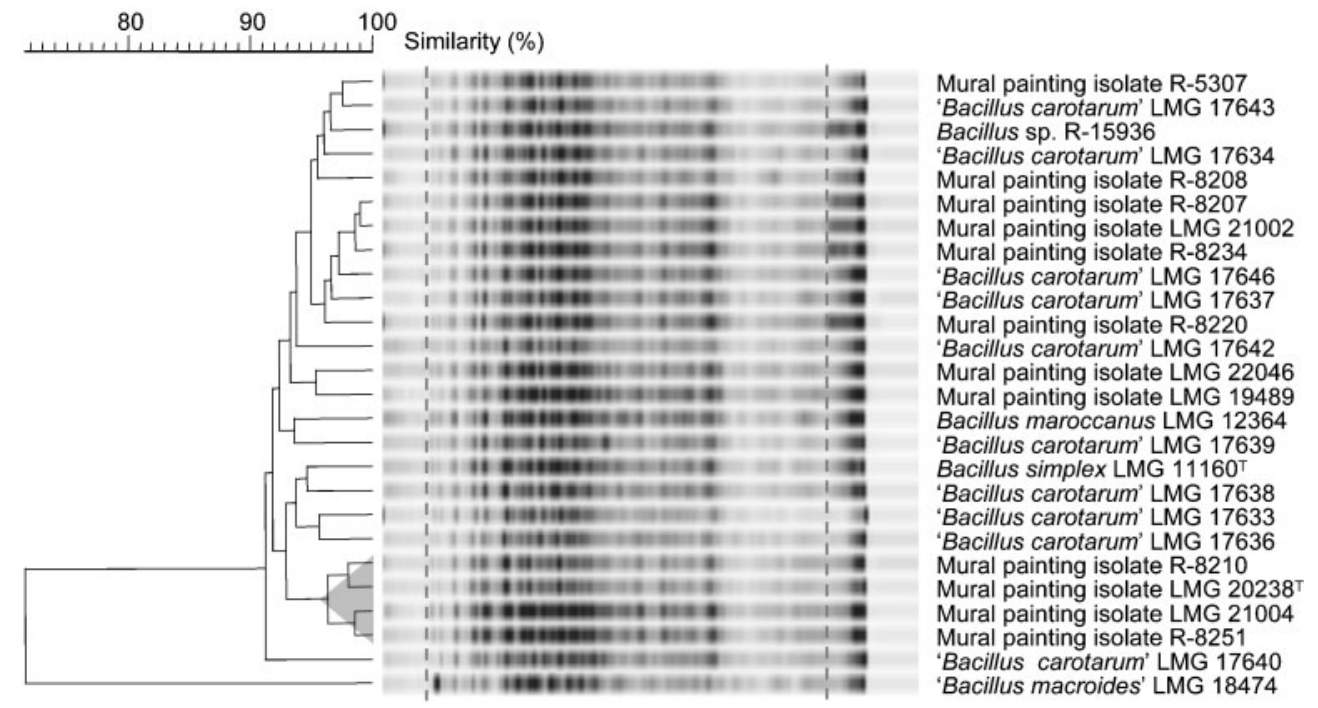

Fig. 4. Normalized computer profiles of protein patterns (PAGE) of mural painting isolates, additional isolates $\mathrm{R}-15936$ and $\mathrm{R}-15943, B$. simplex and named ' $B$. macroides' (strain LMG $18474=\mathrm{DSM} 54=\mathrm{ATCC} 12905$ ), ' $B$. maroccanus' and ' $B$. carotarum' strains. The group containing strains belonging to the novel species $B$. muralis is presented as a shaded triangle. 
comparison with strains of biovars 1 and 2. Biovar 3 contained only strains belonging to $(\mathrm{GTG})_{5}$-group D (B. muralis), but B. muralis strain R-8204 was an outlier of this cluster. When positive and negative reactions were given equal weights in the similarity calculations, $B$. muralis strains LMG $20238^{\mathrm{T}}$, LMG 21004, R-8210 and R-8251 merged at $90 \% S_{\mathrm{G}}$, and this group was joined by R-8204 at $85 \%$, but strains of Bacillus shackletonii and B. simplex (LMG 17636 and LMG 17643) also joined at this level. However, when individual API tests are considered, $B$. muralis R-8204 can be differentiated from B. simplex strains (including LMG 17636 and LMG 17643) by acid production from D-galactose, lactose, D-mannose and melibiose. In addition, all of the B. muralis strains can be separated from $B$. simplex on the basis of the ONPG test and the colour of the diffusible pigment produced on skimmed milk agar (brown for B. simplex strains and salmon-orange for B. muralis strains), and from
B. shackletonii on the basis of several API tests and some non-API characters (Table 3). The differentiation of $B$. simplex and B. muralis from other related Bacillus species can also be achieved using the characters shown in Table 3 .

To investigate further the differentiation of $B$. muralis from B. simplex, two biovar 3 strains (LMG $20238^{\mathrm{T}}$ and R-8204) and six biovar 1 and 2 strains (LMG $11160^{\mathrm{T}}$, LMG 17633, LMG 17636, LMG 17644, LMG 17646 and R-8208) were characterized using the Biotype 100 carbon source assimilation kit (bioMérieux). The patterns of substrate utilization of the tested B. simplex biovar 1 and 2 strains were similar, but they were quite distinct from those of the biovar 3 (B. muralis) strains. B. muralis could be differentiated from $B$. simplex by assimilation of $\mathrm{D}$ galactose, $\alpha$-lactose, D-mannose, $\alpha$-D-melibiose and $\mathrm{D}$ turanose, and failure to assimilate L-aspartate, caprylate, fumarate, gentisate, $m$-hydroxybenzoate, L-malate, mucate,

Table 3. Characters that distinguish between B. simplex (divided into biovars 1 and 2), B. muralis sp. nov. and some phenotypically similar and phylogenetically related Bacillus species

Reference species: 1, B. megaterium; 2, B. flexus (morphological characters, starch and casein hydrolysis data taken from Priest et al., 1988); 3, B. shackletonii; 4, B. firmus (starch hydrolysis data from Priest et al., 1988); 5, B. sporothermodurans; 6, B. oleronius. Symbols: +, >85\% positive; +/W, positive or weakly positive; $\mathrm{W}$, weakly positive; $\mathrm{V}$, variable (26-74\% positive); V/W, variable and when positive weak; -, $0-15 \%$ positive. With the exception of microscopic observations, anaerobic growth, starch and casein hydrolysis, all characters were determined using tests in API 20E and 50CHB.

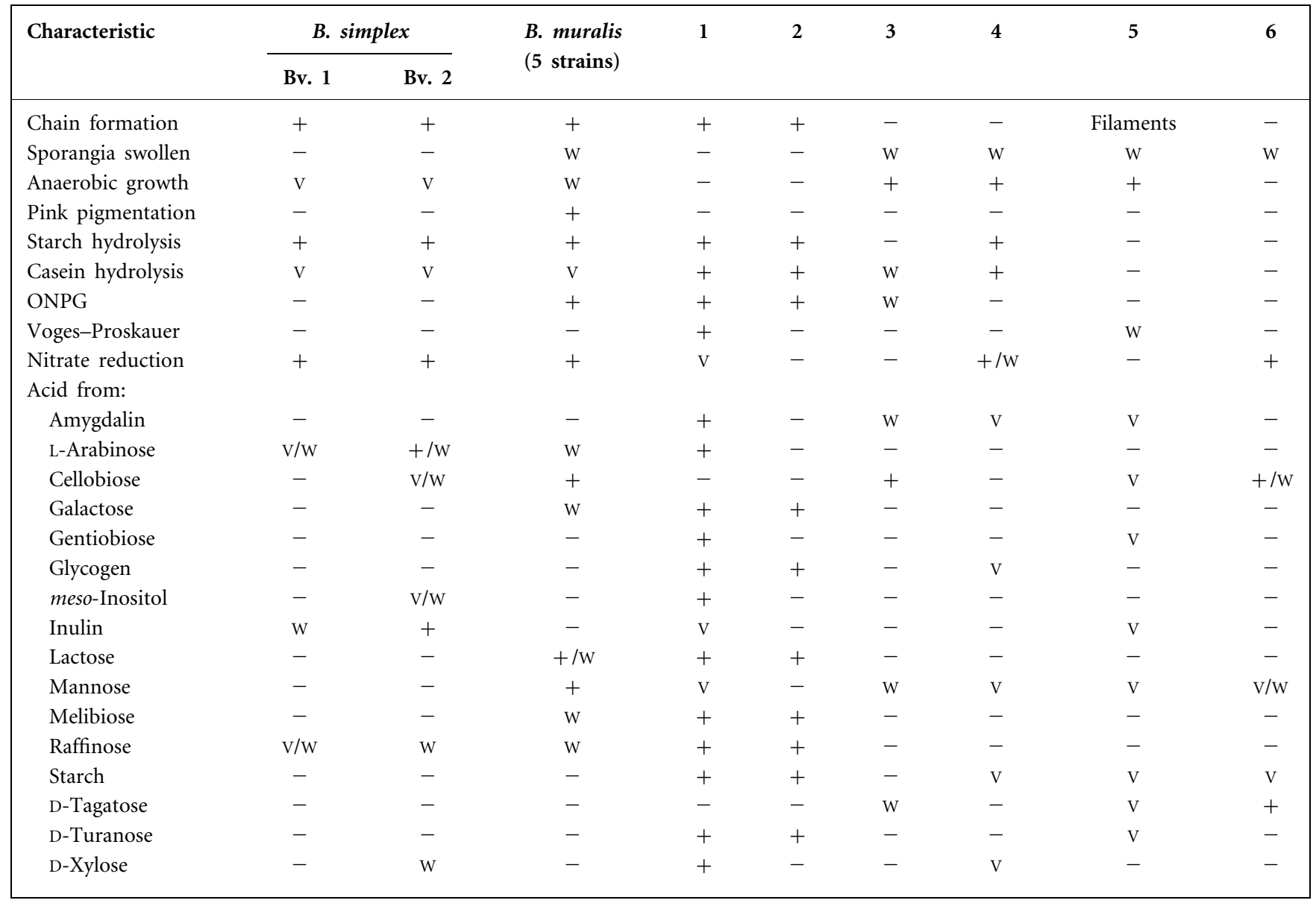


D-saccharate and succinate. The authentic ' $B$. macroides' strain LMG 18474 (=DSM 54=ATCC 12905) was unable to grow on most of the carbon sources. This again confirms its distinctness from B. simplex and B. muralis.

\section{Taxonomy}

The possible synonymy of the species 'B. carotarum' (Koch, 1888) and B. simplex (Gottheil, 1901) was already recognized in the original description of the latter species. Several other possible synonyms were also mentioned in the early literature for 'B. carotarum': 'B. cohaerens' (Gottheil, 1901), 'B. capri', 'B. cobayae' and 'B. musculi' (Stapp, 1920). Since the original ' $B$. carotarum' strains were lost, Gibson \& Gordon (1974) proposed 'B. capri' strain NRS 607 as the representative strain of this species. For some time, ' $B$. carotarum' and its synonyms were thought to belong to B. megaterium (Smith et al., 1946). B. megaterium was considered to consist of two main groups of strains with similar properties as well as some intermediate strains (Gordon et al., 1973). One main group of strains corresponded closely to the original description of $B$. megaterium (de Bary, 1884), while the other included strains of ' $B$. capri' (including NRS 607), 'B. cobayae', B. simplex and 'Bacillus teres'. Later, Hunger \& Claus (1981) showed that the two main B. megaterium groups differed in $\mathrm{G}+\mathrm{C}$ content and that the DNA-DNA relatedness between the groups was well below $70 \%$. Within the second group, these authors found DNA-DNA relatedness values of $70 \%$ or higher between 'B. capri' (strain NRS 607), 'B. cobayae' and 'B. musculi. Between B. simplex strains and ' $B$. capri' values of $67-71 \%$ were obtained. ' $B$. teres' gave 57 and $64 \%$ DNADNA relatedness values with ' $B$. capri' and ' $B$. musculi', respectively. Thus, Hunger \& Claus (1981) showed that ' $B$. carotarum' (represented by 'B. capri') could be attributed to a single genospecies together with B. simplex, ' $B$. cobayae' and ' $B$. musculi'. Further, it was shown that this genospecies differed from B. megaterium. However, the authors did not propose taxonomic changes in their paper, but rather stated that more DNA pairing studies had to be performed. Priest et al. (1988) studied 368 strains, at that time attributed to Bacillus, by 118 phenotypic tests. This study included strains named as ' $B$. carotarum', B. simplex and ' $B$. teres'. In the resulting clustering, B. simplex and ' $B$. teres' grouped together and were closely joined by ' $B$. carotarum' strains. Despite this close relatedness and regardless of the DNA-DNA hybridization data of Hunger \& Claus (1981), Priest et al. (1988) concluded from their study that ' $B$. carotarum' and $B$. simplex were distinct taxa and gave a species description of $B$. simplex (including the ' $B$. teres' strain). The name B. simplex was later validated (Priest et al., 1989).

In the present study 'B. carotarum' strain NRS 607 (=LMG 17637) was included together with other named ' $B$. carotarum' strains and the B. simplex type strain. The data led to the conclusion that strains belonging to ' $B$. carotarum' and its suggested synonyms ' $B$. capri', 'B. cobayae' and 'B. musculi' must be allocated to $B$. simplex. In addition, strains belonging to ' $B$. maroccanus' and ' $B$. macroides' NCIMB 8796 (= NCDO 1661 = LMG 18508) should be reclassified as $B$. simplex, as could already be suspected from their close phylogenetic relatedness (Ash et al., 1991; Xu \& Côté, 2003). Another 'B. macroides' strain, ATCC 12905 (=DSM $54=$ LMG 18474), that can most probably be regarded as the original representative of this species, shares highest $3^{\prime}$-end 16S rRNA gene and $5^{\prime}$-end 16S-23S ITS sequence similarity with B. fusiformis and B. sphaericus (Xu \& Côté, 2003). Whether this ' $B$. macroides' representative deserves separate species rank is still open to investigation. Most mural painting isolates investigated in this study, as well as isolates R-15936 and R-15943, were also attributed to B. simplex. In addition, a group of five mural painting isolates, recognized on the basis of genotypic and phenotypic analyses, is proposed as the novel species Bacillus muralis and a description follows.

\section{Description of Bacillus muralis sp. nov.}

Bacillus muralis (mu.ra'lis. L. masc. adj. muralis pertaining or belonging to walls).

Cells are rod-shaped, $0 \cdot 7-0 \cdot 8 \mu \mathrm{m}$ in diameter, and occur singly, in pairs or chains. They are straight with round or occasionally slightly tapered ends. They are motile when occurring singly but non-motile when in chains. Endospores are ellipsoidal, lie centrally or paracentrally and do not swell the sporangia or swell them only slightly. Gram reaction is variable. Colonies grown for 2 days on nutrient agar at $30^{\circ} \mathrm{C}$ are $3-6 \mathrm{~mm}$ in diameter, butyrous, pinkpigmented, glossy, with irregular margins, slightly raised and umbonate. Growth under anaerobic conditions on nutrient agar is weak. Optimal growth at $30^{\circ} \mathrm{C}$, weak growth at $20^{\circ} \mathrm{C}$ and no growth at $45^{\circ} \mathrm{C}$. Strains grow at pH 9 less profusely than at $\mathrm{pH} 7$ and growth at $\mathrm{pH} 5$ is negative. Casein hydrolysis is variable and a diffusible salmon-pink tint appears in the medium. Starch is hydrolysed. Strains tolerate $7 \% \mathrm{NaCl}$, but grow weakly. Oxidase and catalase reactions are positive.

In the API 20E strip, the ONPG reaction is positive. Arginine dihydrolase, lysine decarboxylase and ornithine decarboxylase reactions are negative, citrate is not utilized, hydrogen sulphide and indole are not produced, urease production and the Voges-Proskauer reaction are negative and gelatin is not hydrolysed. Nitrate is reduced to nitrite. In the API 50 CHB gallery, hydrolysis of aesculin is positive and acid is produced (sometimes weakly)without gas from the following carbohydrates: L-arabinose, arbutin, cellobiose, fructose, galactose, $N$-acetylglucosamine, glucose, glycerol, lactose, maltose, mannitol, mannose, melibiose, raffinose, ribose, trehalose and salicin. Results are variable for acid production from sucrose. Acid is not produced from the following carbohydrates: adonitol, amygdalin, D-arabinose, D- and L-arabitol, dulcitol, erythritol, D- and L-fucose, gentiobiose, gluconate, glycogen, inositol, inulin, 2- and 5ketogluconate, D-lyxose, melezitose, methyl $\alpha$-D-glucoside, methyl $\alpha$-D-mannoside, methyl $\beta$-D-xyloside, rhamnose, 
starch, sorbitol, sorbose, D-tagatose, D-turanose, D- and Lxylose and xylitol.

The major cellular fatty acids are anteiso- $\mathrm{C}_{15: 0}$ and iso$\mathrm{C}_{15: 0}$, present at about 43 and $23 \%$ of the total fatty acids, respectively. The following fatty acids are present at $\geqslant 1 \%$ : iso- $\mathrm{C}_{14: 0}, \mathrm{C}_{14: 0}, \mathrm{C}_{15: 0}, \mathrm{C}_{16: 1} \omega 7 c$ alcohol, iso- $\mathrm{C}_{16: 0}$, $\mathrm{C}_{16: 1} \omega 11 c$ and $\mathrm{C}_{16: 0}$. The $\mathrm{G}+\mathrm{C}$ content is $41 \cdot 2 \mathrm{~mol} \%$ for the type strain.

The type strain, strain LMG $20238^{\mathrm{T}}$ (=DSM $16288^{\mathrm{T}}$ ), was isolated from mural paintings in the Lutheran church of Greene-Kreiensen, Germany. In the characters for which a variable result was obtained, the type strain does not hydrolyse casein and does not produce acid from sucrose. In the Biotype 100 kit, the type strain hydrolyses aesculin and is able to grow on the following substrates as sole carbon sources: cis- and trans-aconitate, D- and L-alanine, 4-aminobutyrate, 5-aminovalerate, L-arabinose, L-arabitol, $\mathrm{D}$-cellobiose, citrate, $\beta$-D-fructose, D-galactose, $\beta$-gentiobiose, D-gluconate, D-glucosamine, $\alpha$-D-glucose, glycerol, L-histidine, 3-hydroxybutyrate, 2-oxoglutarate, DL-lactate, $\alpha$-lactose, maltose, maltotriose, D-mannitol, D-mannose, $\alpha$-D-melibiose, methyl $\alpha$-D-glucopyranoside, $N$-acetyl-Dglucosamine, palatinose, phenylacetate, L-proline, putrescine, D-raffinose, D-ribose, L-serine, sucrose, D-trehalose, L-tryptophan, D-turanose, L-tyrosine and D-xylose.

\section{Emended description of Bacillus simplex (ex Meyer and Gottheil 1901) Priest et al. 1989}

Bacillus simplex (sim'plex. L. masc. adj. simplex simple).

Rods are straight, $0 \cdot 7-0.9 \mu \mathrm{m}$ in diameter, round-ended or occasionally slightly tapered and occur in chains and sometimes singly or in pairs. Motile when occurring singly but non-motile when growing in chains. Endospores are ellipsoidal, occasionally spherical, lie centrally, paracentrally or subterminally, and do not obviously swell the sporangia. Gram reaction is variable amongst cells. Colonies, grown for 2 days on nutrient agar at $30{ }^{\circ} \mathrm{C}$, are $3-6 \mathrm{~mm}$ in diameter, cream-coloured, glossy, with irregular margins, slightly raised and umbonate. Most strains are strictly aerobic, although some strains may grow weakly on nutrient agar under anaerobic conditions. They grow at 20 and $30{ }^{\circ} \mathrm{C}$ but are not able to grow at $45^{\circ} \mathrm{C}$. Strains grow at $\mathrm{pH} 9$ as profusely as at $\mathrm{pH} 7$ and growth at $\mathrm{pH} 5$ is variable. Casein hydrolysis is variable and a brown tint, of varying strength, diffuses into the medium. Starch is hydrolysed. Tolerance to $5 \% \mathrm{NaCl}(\mathrm{w} / \mathrm{v})$ is variable and no growth occurs in media supplemented with $7 \% \mathrm{NaCl}(\mathrm{w} / \mathrm{v})$. Oxidase reaction is negative and catalase is positive. In the API 20E strip, the ONPG, arginine dihydrolase, lysine decarboxylase and ornithine decarboxylase reactions are negative, citrate is not utilized, hydrogen sulphide and indole are not produced, urease production and the Voges-Proskauer reaction are negative and gelatin hydrolysis is variable. Nitrate is reduced to nitrite. In the API $50 \mathrm{CHB}$ gallery, hydrolysis of aesculin is variable and weak. For all strains tested, acid is produced, mostly weakly, without gas from the following carbohydrates: fructose, $N$-acetylglucosamine, glucose, inulin, trehalose and sucrose. Strains produce acid weakly and variably from salicin. Acid production is always negative from adonitol, amygdalin, D-arabinose, D- and L-arabitol, arbutin, dulcitol, erythritol, D- and L-fucose, galactose, gentiobiose, gluconate, 2- and 5-keto-D-gluconate, glycogen, lactose, D-lyxose, mannose, melezitose, melibiose, methyl $\alpha$-D-glucoside, methyl $\alpha$-D-mannoside, methyl $\beta$-D-xyloside, rhamnose, starch, sorbose, D-tagatose, D-turanose, L-xylose and xylitol. On the basis of reaction patterns for other substrates, two biovars may be recognized: strains belonging to biovar 1 produce acid weakly and variably from L-arabinose, mannitol, raffinose, ribose and sorbitol, while acid production is always negative from cellobiose, glycerol, inositol, maltose and D-xylose; strains of biovar 2 produce acid, weakly, without gas from the following carbohydrates: L-arabinose, mannitol, raffinose, ribose, sorbitol and D-xylose; biovar 2 strains are variable for weak acid production from cellobiose, glycerol, inositol and maltose.

The major cellular fatty acids are anteiso- $\mathrm{C}_{15: 0}$ and iso$\mathrm{C}_{15: 0}$, present (means $\pm \mathrm{SD}$ ) at $59 \cdot 03 \pm 5 \cdot 88$ and $15 \cdot 55 \pm$ $2.95 \%$ of total fatty acids, respectively. The following fatty acids are present (mean values) at $\geqslant 1 \%$ : iso- $\mathrm{C}_{14: 0}$ $(5 \cdot 94 \pm 2 \cdot 82 \%), \mathrm{C}_{14: 0}(1 \cdot 56 \pm 0.59 \%), \mathrm{C}_{16: 1} \omega 7 c$ alcohol $(2 \cdot 97 \pm 0.74 \%), \quad$ iso- $\mathrm{C}_{16: 0} \quad(2 \cdot 26 \pm 1 \cdot 42 \%), \mathrm{C}_{16: 1} \omega 11 c$ $(4 \cdot 80 \pm 1 \cdot 30 \%), \mathrm{C}_{16: 0}(2 \cdot 36 \pm 1 \cdot 58 \%)$, iso- $\mathrm{C}_{17: 1} \mathrm{I}$ and/or anteiso- $\mathrm{C}_{17: 1} \mathrm{~B}(1 \cdot 12 \pm 0 \cdot 82 \%)$, and anteiso- $\mathrm{C}_{17: 0}(1 \cdot 82 \pm$ $0 \cdot 80 \%)$. The $\mathrm{G}+\mathrm{C}$ content is in the range of $39 \cdot 5-$ $41 \cdot 8 \mathrm{~mol} \%$.

The type strain is strain NRS $960^{\mathrm{T}}\left(=\right.$ ATCC $49097^{\mathrm{T}}=\mathrm{DSM}$ $1321^{\mathrm{T}}=\mathrm{LMG} 11160^{\mathrm{T}}$ ). For the variable characters in the API kits, the results for the type strain are as follows: weak or moderate acid production for L-arabinose, mannitol, ribose and sorbitol. No acid is produced from raffinose. In the Biotype $100 \mathrm{kit}$, the type strain hydrolyses aesculin very weakly and is able to grow on the following substrates as sole carbon sources: cis- and trans-aconitate, D- and L-alanine, 4-aminobutyrate, 5-aminovalerate, L-aspartate, benzoate, caprylate, citrate, $m$-coumarate, ethanolamine, $\beta$-D-fructose, fumarate, gentisate, $\mathrm{D}$-gluconate, D-glucosamine, $\alpha$-D-glucose, $\mathrm{D}$-glucuronate, L-glutamate, glutarate, DL-glycerate, glycerol, L-histidine, $m$-hydroxybenzoate, 3-hydroxybutyrate, myo-inositol, 2-keto-D-gluconate, DLlactate, L-malate, maltose, maltotriose, D-mannitol, methyl $\alpha$-galactopyranoside, mucate, $N$-acetyl-D-glucosamine, palatinose, phenylacetate, 3-phenylpropionate, L-proline, propionate, protocatechuate, putrescine, quinate, $\alpha-\mathrm{L}$ rhamnose, D-ribose, D-saccharate, L-serine, D-sorbitol, succinate, L-tartrate, D-trehalose, tricarballylate, L-tryptophan, L-tyrosine and D-xylose.

\section{ACKNOWLEDGEMENTS}

The authors acknowledge financial support from the European Commission (grant ENV4-CT98-0705). We are most grateful to 
bioMérieux for providing API materials and for supporting M. R.-D. The authors are grateful to Mrs Sandra Cots and Mrs Elly Engels for excellent technical assistance.

\section{REFERENCES}

Ash, C., Farrow, J. A. E., Wallbanks, S. \& Collins, M. D. (1991). Phylogenetic heterogeneity of the genus Bacillus revealed by comparative analysis of small-subunit-ribosomal RNA sequences. Lett Appl Microbiol 13, 202-206.

Bennett, J. F. \& Canale-Parola, E. (1965). The taxonomic status of Lineola longa. Arch Mikrobiol 52, 197-205.

Claus, D. \& Berkeley, R. C. W. (1986). Genus Bacillus Cohn 1872. In Bergey's Manual of Systematic Bacteriology, vol. 2, pp. 1105-1139. Edited by P. H. A. Sneath, N. S. Mair, M. E. Sharpe \& J. G. Holt. Baltimore: Williams \& Wilkins.

De Bary, A. (1884). Vergleichende Morphologie und Biologie der Pilze, Mycetozoen und Bakterien. Leipzig: Wilhelm Engelmann (in German).

Delaporte, B. \& Sasson, A. (1967). Étude des bactéries des sols arides du Maroc: Bacillus maroccanus n. sp. C R Acad Sci Serie D 264, 2344-2346 (in French).

Ezaki, T., Hashimoto, Y. \& Yabuuchi, E. (1989). Fluorometric deoxyribonucleic acid-deoxyribonucleic acid hybridization in microdilution wells as an alternative to membrane filter hybridization in which radioisotopes are used to determine genetic relatedness among bacterial strains. Int J Syst Bacteriol 39, 224-229.

Gibson, T. \& Gordon, R. E. (1974). Bacillus. In Bergey's Manual of Determinative Bacteriology, 8th edn, pp. 529-550. Edited by R. E. Buchanan \& N. E. Gibbons. Baltimore: Williams \& Wilkins.

Gordon, R. E., Haynes, W. C. \& Pang, C. H.-N. (1973). The Genus Bacillus. Agricultural Handbook no. 427. Washington, DC: US Department of Agriculture.

Goto, K., Omura, T., Hara, Y. \& Sadaie, Y. (2000). Application of the partial $16 \mathrm{~S}$ rDNA sequence as an index for rapid identification of species in the genus Bacillus. J Gen Appl Microbiol 46, 1-8.

Gottheil, O. (1901). Botanische Beschreibung einiger Bodenbakterien. Zentbl Bakteriol Parasitenkd Infektionskr Hyg Abt II 7, 680-691 (in German).

Heyndrickx, M., Vauterin, L., Vandamme, P., Kersters, K. \& De Vos, P. (1996). Applicability of combined amplified ribosomal DNA restriction analysis (ARDRA) patterns in bacterial phylogeny and taxonomy. J Microbiol Methods 26, 247-259.

Heyndrickx, M., Lebbe, L., Vancanneyt, M. \& 7 other authors (1997). A polyphasic reassessment of the genus Aneurinibacillus, reclassification of Bacillus thermoaerophilus (Meier-Stauffer et al. 1996) as Aneurinibacillus thermoaerophilus comb. nov., and emended descriptions of $A$. aneurinilyticus corrig., A. migulanus, and A. thermoaerophilus. Int J Syst Bacteriol 47, 808-817.

Heyndrickx, M., Lebbe, L., Kersters, K., De Vos, P., Forsyth, G. \& Logan, N. A. (1998). Virgibacillus: a new genus to accommodate Bacillus pantothenticus (Proom and Knight 1950). Emended description of Virgibacillus pantothenticus. Int J Syst Bacteriol 48, 99-106.

Heyrman, J. \& Swings, J. (2001). 16S rDNA sequence analysis of bacterial isolates from biodeteriorated mural paintings in the Servilia tomb (necropolis of Carmona, Seville, Spain). Syst Appl Microbiol 24, 417-422.

Heyrman, J., Mergaert, J., Denys, R. \& Swings, J. (1999). The use of fatty acid methyl ester analysis (FAME) for the identification of heterotrophic bacteria present on three mural paintings showing severe damage by microorganisms. FEMS Microbiol Lett 181, 55-62.
Heyrman, J., Logan, N. A., Busse, H.-J., Balcaen, A., Lebbe, L., Rodriguez-Diaz, M., Swings, J. \& De Vos, P. (2003). Virgibacillus carmonensis sp. nov., Virgibacillus necropolis sp. nov. and Virgibacillus picturae sp. nov., three novel species isolated from deteriorated mural paintings, transfer of the species of the genus Salibacillus to Virgibacillus, as Virgibacillus marismortui comb. nov. and Virgibacillus salexigens comb. nov., and emended description of the genus Virgibacillus. Int J Syst Evol Microbiol 53, 501-511.

Hunger, W. \& Claus, D. (1981). Taxonomic studies on Bacillus megaterium and on agarolytic Bacillus strains. In The Aerobic Endospore-forming Bacteria: Classification and Identification, pp. 217239. Edited by R. C. W. Berkeley \& M. Goodfellow. London \& New York: Academic Press.

Kämpfer, P. (1994). Limits and possibilities of total fatty acid analysis for classification and identification of Bacillus species. Syst Appl Microbiol 17, 86-98.

Koch, A. (1888). Ueber Morphologie und Entwicklungsgeschichte einiger endosporer Bacterienformen. Bot Ztg 46, 277-287 (in German).

Logan, N. A. \& Berkeley, R. C. W. (1984). Identification of Bacillus strains using the API system. J Gen Microbiol 130, 1871-1882.

Logan, N. A., Lebbe, L., Hoste, B. \& 7 other authors (2000). Aerobic endospore-forming bacteria from geothermal environments in northern Victoria Land, Antarctica, and Candlemas Island, South Sandwich archipelago, with the proposal of Bacillus fumarioli sp. nov. Int J Syst Evol Microbiol 50, 1741-1753.

Marmur, J. (1961). A procedure for the isolation of deoxyribonucleic acid from micro-organisms. J Mol Biol 3, 208-218.

Mergaert, J., Verdonck, L. \& Kersters, K. (1993). Transfer of Erwinia ananas (synonym, Erwinia uredovora) and Erwinia stewartii to the genus Pantoea emend. as Pantoea ananas (Serrano 1928) comb. nov. and Pantoea stewartii (Smith 1898) comb. nov., respectively, and description of Pantoea stewartii subsp. indologenes subsp. nov. Int J Syst Bacteriol 43, 162-173.

Mesbah, M., Premachandran, U. \& Whitman, W. B. (1989). Precise measurement of the $\mathrm{G}+\mathrm{C}$ content of deoxyribonucleic acid by high-performance liquid chromatography. Int J Syst Bacteriol 39, 159-167.

Pearson, W. R. \& Lipman, D. J. (1988). Improved tools for biological sequence comparison. Proc Natl Acad Sci U S A 85, 2444-2448.

Pitcher, D. G., Saunders, N. A. \& Owen, R. J. (1989). Rapid extraction of bacterial genomic DNA with guanidium thiocyanate. Lett Appl Microbiol 8, 151-156.

Pot, B., Vandamme, P. \& Kersters, K. (1994). Analysis of electrophoretic whole organism protein fingerprints. In Chemical Methods in Prokaryotic Systematics, pp. 493-521. Edited by M. Goodfellow \& A. G. O'Donnell. Chichester: Wiley.

Priest, F. G., Goodfellow, M. \& Todd, C. (1988). A numerical classification of the genus Bacillus. J Gen Microbiol 134, 1847-1882.

Priest, F. G., Goodfellow, M. \& Todd, C. (1989). Bacillus simplex sp. nov., nom. rev. In Validation of the Publication of New Names and New Combinations Previously Effectively Published Outside the IJSB, List no. 28. Int J Syst Bacteriol 39, 93-94.

Pringsheim, E. G. (1950). The bacterial genus Lineola. J Gen Microbiol 4, 198-209.

Pringsheim, E. G. \& Robinow, C. F. (1947). Observations on two very large bacteria, Caryophanon latum Peshkoff and Lineola longa (nomen provisorium). J Gen Microbiol 1, 267-278.

Rademaker, J. L. W. \& de Bruijn, F. J. (1997). Characterization and classification of microbes by rep-PCR genomic fingerprinting and computer assisted pattern analysis. In DNA Markers: Protocols, Applications and Overviews, pp. 151-171. Edited by G. GaetanoAnollés \& P. M. Gresshoff. New York: Wiley. 
Saitou, N. \& Nei, M. (1987). The neighbor-joining method: a new method for reconstructing phylogenetic trees. Mol Biol Evol 4, 406-425.

Scheldeman, P., Goossens, K., Rodríguez-Díaz, M., Pil, A., Goris, J., Herman, L., De Vos, P., Logan, N. A. \& Heyndrickx, M. (2004). Paenibacillus lactis sp. nov., isolated from raw and heat-treated milk. Int J Syst Evol Microbiol 54, 885-891.

Smith, N. R., Gordon, R. E. \& Clarck, F. E. (1946). Aerobic Mesophilic Sporeforming Bacteria. United States Department of Agriculture Miscellaneous Publication no. 559. Washington, DC: US Department of Agriculture.

Stackebrandt, E., Frederiksen, W., Garrity, G. M. \& 10 other authors (2002). Report of the ad hoc committee for the re-evaluation of the species definition in bacteriology. Int J Syst Evol Microbiol 52, 1043-1047.

Stapp, C. (1920). Botanische Untersuchungen einiger neuer Bakterien-spezies, welche mit reiner Harnsäure oder Hippursäure als all-einigem organischem Nährstoff auskommen. Zentbl Bakteriol Parasitenkd Infektionskr Hyg Abt II 51, 1-71 (in German).

Vauterin, L. \& Vauterin, P. (1992). Computer aided objective comparison of electrophoretic patterns for grouping and identification of microorganisms. Eur Microbiol 1, 37-41.

Versalovic, J., Schneider, M., de Bruijn, F. J. \& Lupski, J. R. (1994). Genomic fingerprinting of bacteria using repetitive sequence-based polymerase chain reaction. Methods Mol Cell Biol 5, 25-40.

Willems, A., Doignon-Bourcier, F., Goris, J., Coopman, R., de Lajudie, P., De Vos, P. \& Gillis, M. (2001). DNA-DNA hybridization study of Bradyrhizobium strains. Int $J$ Syst Evol Microbiol 51, 1315-1322.

Xu, D. \& Côté, J.-C. (2003). Phylogenetic relationships between Bacillus species and related genera inferred from comparison of $3^{\prime}$ end 16S rDNA and $5^{\prime}$ end 16S-23S ITS nucleotide sequences. Int J Syst Evol Microbiol 53, 695-704. 